\title{
Lembar Kerja Peserta Didik Matematika Berbasis Penemuan Terbimbing Terintegrasi Nilai Keislaman
}

\author{
Arnida Sari ${ }^{1}$, Rena Revita ${ }^{2}$ \\ 1,2,3 Program Studi Pendidikan Matematika, UIN Sultan Syarif Kasim Riau, \\ Jl. HR. Soebrantas, Panam, Riau \\ arnidasari@uin-suska.ac.id
}

\begin{abstract}
The purpose of this research is to develop and produce Mathematics Student Worksheets based on Guided Discovery integrated with Islamic Values for SMP/MTs students that meet a demand of valid, practical, and effective criteria. The type of this research research and development with ADDIE model (Analysis, Design, Development, Implementation, and Evaluation). The subject of this research was student of VIII class on SMP/MTs in Pekanbaru City, expert of matematics, expert of technology of education, and teachers. The object of this research is Mathematics Student Worksheets based on Guided Discovery integrated with Islamic Values. Data collection technique are questionnaire and test. Instruments in this research are form of questionnaire and test questions. Technique of data analysis are qualitative data analysis to analyze the data from comentary and suggestion of expert and subject of this research and quantitative data analysis techniques to analyze data from questionnaire and result of student test. The result showed that based on the validity test with expert, the mathematics student worksheets based on guided discovery integrated with islamic values was declared very valid with the percentage of technology experts $96.30 \%$, mathematics experts $97.03 \%$ and Islamic material experts $83.4 \%$. The results of the small group practicality test showed that the mathematics student worksheets based on guided discovery integrated with islamic values was stated to be very practical with a practicality level percentage of $84 \%$. The results of the effectiveness test have an average effectiveness of $81.81 \%$. From these results, it was identified that the mathematics student worksheets based on guided discovery integrated with islamic values were valid, practical, and effective for students to use.
\end{abstract}

Keywords: Mathematics Student Worksheets, Guided Discovery, Islamic Value

\begin{abstract}
Abstrak
Tujuan dari penelitian ini adalah untuk mengembangkan dan menghasilkan Lembar Kerja Peserta Didik Matematika berbasis Penemuan Terbimbing terintegrasi Nilai Keislaman untuk siswa SMP/MTs yang memenuhi kriteria valid, praktis dan efektif. Jenis penelitian ini merupakan penelitian pengembangan (Research and Development) dengan model ADDIE (Analysis, Design, Development, Implementation, dan Evaluation). Subjek penelitian adalah siswa kelas VIII, ahli materi pembelajaran dan ahli teknologi pendidikan yang berasal dari dosen dan guru. Objek penelitian ini adalah LKPD Matematika berbasis Penemuan Terbimbing terintegrasi Nilai Keislaman. Instrumen pengumpulan data berupa angket dan soal tes. Data yang diperoleh kemudian dianalisis dengan teknik analisis data kualitatif untuk menganalisis data yang diperoleh dari hasil saran dan komentar para ahli dan subjek lainnya dan teknik analisis data kuantitatif untuk menganalisis data yang diperoleh dari hasil angket dan tes siswa. Hasil penelitian menunjukkan bahwa berdasarkan uji validitas, LKPD Matematika berbasis Penemuan Terbimbing terintegrasi Nilai Keislaman dinyatakan sangat valid dengan persentase ahli teknologi 96,30\%, Ahli materi pembelajaran 97,03\% dan ahli materi keislaman 83,4\%. Hasil uji praktikalitas kelompok kecil diperoleh bahwa LKPD Matematika berbasis Penemuan Terbimbing terintegrasi Nilai Keislaman dinyatakan sangat praktis dengan persentase tingkat kepraktisan $84 \%$. Hasil Uji keefektifan memiliki keefektifan yang rata-rata $81,81 \%$. Dari hasil tersebut mengidentifikasi bahwa LKS yang dikembangkan valid, praktis dan efektif untuk dapat digunakan siswa.
\end{abstract}

Kata Kunci: Lembar Kerja Peserta Didik (LKPD) Matematika, Penemuan Terbimbing, Nilai Keislaman

Copyright (c) 2022 Arnida Sari, Rena Revita

$\triangle$ Corresponding author: Rena Revita

Email Address: rena.revita@uin-suska.ac.id (Jl. HR. Soebrantas, Panam, Riau)

Received 01 January 2022, Accepted 02 February 2022, Published 06 February 2022

\section{PENDAHULUAN}

Kemampuan komunikasi matematis merupakan salah satu kemampuan dasar dalam pembelajaran matematika yang harus dimiliki oleh peserta didik. Oleh karena itu matematika sebagai suatu mata pelajaran yang wajib diikuti oleh peserta didik di sekolah memiliki standar proses 
kemampuan yang harus dicapai. Sebagaimana yang tercantum di dalam Permendikbud Nomor 21 Tahun 2016 tentang Standar Isi Pendidikan Dasar dan Menengah menetapkan bahwa kompetensi yang harus dicapai pada pelajaran matematika (Permendikbud, 2016) :

1. Menunjukkan sikap logis, kritis, analitis, kreatif, cermat dan teliti, bertanggung jawab, responsif, dan tidak mudah menyerah dalam memecahkan masalah.

2. Memiliki rasa ingin tahu, semangat belajar yang kontinu, rasa percaya diri, dan ketertarikan pada matematika.

3. Memiliki rasa percaya pada daya dan kegunaan matematika, yang terbentuk melalui pengalaman belajar.

4. Memiliki sikap terbuka, objektif dalam interaksi kelompok maupun aktivitas sehari-hari.

5. Memiliki kemampuan mengkomunikasikan gagasan matematika dengan jelas.

Berdasarkan hal tersebut, terlihat bahwa kemampuan komunikasi menjadi salah satu kemampuan dasar matematika yang harus dimiliki oleh perserta didik di sekolah. Pentingnya kemampuan komunikasi dalam matematika juga dijelaskan oleh Yeni (Yuniarti, 2014) kemampuan komunikasi dalam pembelajaran matematika perlu ditumbuhkembangkan dikalangan peserta didik, karena matematika tidak hanya sekedar alat bantu berfikir, alat untuk menemukan pola, menyelesaikan masalah atau mengambil kesimpulan tetapi matematika juga sebagai aktivitas sosial dalam pembelajaran matematika, matematika sebagai wahana interaksi antar peserta didik dan juga komunikasi antara guru dan peserta didik

Namun, di lapangan sering kali terdapat permasalahan-permasalahan yang berkaitan dengan komunikasi matematika. Secara umum, berdasarkan beberapa penelitian yang membahas mengenai komunikasi matematika peserta didik, terlihat beberapa gejala yang sering muncul dalam proses pembelajaran, diantaranya sebagai berikut :

1. Peserta didik belum mampu mengungkapkan ide-ide matematika ke dalam bentuk gambar dan grafik, hal ini terlihat dari kurangnya kemampuan peserta didik dalam menjawab soal matematika yang menggunakan gambar atau membuat grafik.

2. Peserta didik belum mampu membuat model matematika dari permasalahan matematika yang dihadapi, misalnya dalam penyelesaian soal cerita.

3. Peserta didik kurang mampu memberikan penjelasan secara matematika dalam penyelesaian permasalahan matematika dengan bahasa yang jelas dan mudah dipahami.

4. Dalam proses pembelajaran yang menerapkan diskusi kelompok yang membutuhkan presentasi dan tanya jawab, hanya sedikit peserta didik yang mampu berbicara dan menjelaskan di depan kelas, dan cenderung peserta didik yang sama.

5. Pada akhir pembelajaran peserta didik belum mampu membuat kesimpulan mengenai materi yang telah dipelajari di kelas

Berdasarkan gejala-gejala tersebut, persoalannya adalah bagaimana caranya seorang guru mampu membuat suatu proses pembelajaran di kelas yang menarik, menyenangkan dan bermakna 
Lembar Kerja Peserta Didik Matematika Berbasis Penemuan Terbimbing Terintegrasi Nilai Keislaman, Arnida Sari, Rena Revita

agar dapat meningkatkan komunikasi matematika siswa dengan sebaik-baiknya. Kegiatan peserta didik akan lebih mudah diselesaikan dan dituangkan melalui lembar kerja yang sudah terarah dengan atau tanpa bantuan guru. Untuk itu sangat dibutuhkan kemampuan guru dalam merancang dan mengembangkan LKPD sebelum melaksanakan pembelajaran di Kelas. Berdasarkan tahap-tahap yang ada, diupayakan agar peserta didik juga mampu memiliki kemampuan komunikasi matematis untuk mendapatkan hasil yang diharapkan. Selain itu, menurut Kosasih (Kosasih, 2014) untuk mencapai hasil pembelajaran matematika yang efektif, dalam kegiatan pembelajaran di kelas perlu menggunakan prinsip-prinsip yakni:

1. Berpusat pada peserta didik,

2. Mengembangkan kreativitas peserta didik,

3. Menciptakan kondisi menyenangkan dan menantang,

4. Bermuatan nilai, etika, estetika, logika, dan kinestetika,

5. Menyediakan pengalaman belajar yang beragam melalui penerapan berbagai strategi pembelajaran dan model pembelajaran yang menyenangkan, kontekstual, efektif, efisien dan bermakna.

Berdasarkan hal tersebut, maka terlihat bahwa salah satu prinsip pembelajaran di kelas harus memiliki prinsip menyediakan pengalaman belajar yang beragam melalui penerapan berbagai strategi pembelajaran dan model pembelajaran yang menyenangkan, kontekstual, efektif, efisien dan bermakna. Untuk itu, dalam perencanaan pembelajaran, guru harus mampu merancang proses pembelajaran yang menerapkan model atau strategi yang dapat menunjang proses pembelajaran agar tercapainya tujuan pembelajaran. Salah satu model pembelajaran yang dapat diterapkan adalah model pembelajaran penemuan terbimbing.

Model penemuan terbimbing merupakan suatu cara penyampaian topik matematika sedemikian rupa sehingga dalam proses pembelajaran memungkinkan peserta didik menemukan sendiri pola-pola atau struktur-struktur matematika melalui pengalaman belajar yang telah lalu dan tidak lepas dari pengawasan serta bimbingan guru, (Risnawati, 2008). Bimbingan tersebut dapat dilakukan melalui instruksi lisan ataupun tulisan untuk memperlancar belajar suatu konsep atau hubungan-hubungan matematika. Selain itu, Destrini (Destrini, Nirwana, \& Sakti, 2018) menyatakan bahwa melalui model penemuan terbimbing, peserta didik dapat mengembangkan pemikiran dalam belajar tentang sains. Pendapat ini juga didukung oleh Veta (Fitriani \& Afri, 2020) yang menyatakan bahwa peserta didik menjadi lebih aktif baik secara mandiri maupun berkelompok dan didukung dengan bantuan LKPD dalam proses pembelajaran dan peserta didik dapat mengkonstruksi pemahaman mereka secara mandiri. Hal tersebut menunjukkan bahwa dengan menggunakan model penemuan terbimbing, peserta didik dapat terlatih untuk mengungkapkan ide matematika secara tertulis melalui bimbingan dalam bentuk tulisan dan dapat mengungkapkan ide matematika secara lisan dengan mendapatkan bimbingan secara lisan oleh guru. 
Hal ini didukung oleh beberapa penelitian yang membahas mengenai penemuan terbimbing yang telah dilakukan, salah satunya penelitian yang telah dilakukan Dede (2016) yang berjudul "Penerapan Metode Penemuan Terbimbing Untuk Meningkatkan Kemampuan Pemecahan Masalah Matematis, Kemampuan Komunikasi Matematis, dan Analisis Kemandirian Belajar peserta didik SMA" yang menyimpulkan bahwa berdasarkan hasil penelitian diperoleh kesimpulan bahwa peningkatan kemampuan komunikasi matematis peserta didik yang mengikuti pembelajaran menggunakan metode penemuan terbimbing lebih baik dari pada peserta didik yang pembelajarannya menggunakan penemuan terbimbing. Selain itu penelitian yang telah dilakukan oleh Ariesta dan Awwaludin (2021) yang berjudul "Pengaruh Model Pembelajaran Penemuan Terbimbing Berbantuan LKPD Terhadap Kemampuan Komunikasi Matematis Siswa”, didukung juga sebelumnya penelitian oleh sani dkk (Sani, Hartoyo, \& Yani, 2017; Suparsih, 2018) juga menunjukkan hasil yang menyatakan bahwa pembelajaran dengan menggunakan pendekatan penemuan terbimbing dapat mejadikan kemampuan komunikasi peserta didik menjadi lebih baik.

Uraian-uraian tersebut menegaskan bahwa dalam pembelajaran yang menggunakan model penemuan terbimbing, peserta didik terlibat secara aktif dalam melakukan penemuan dan guru aktif memberikan bimbingan baik secara tulisan maupun lisan. Pembelajaran juga akan berlangsung secara bertahap dan menciptakan lingkungan yang memungkinkan peserta didik melalui proses penemuan sehingga kemampuan peserta didik untuk berkomunikasi baik itu secara lisan maupun tulisan dapat terlatih dengan baik.

Selama proses penemuan peserta didik mendapat bimbingan guru baik berupa lisan maupun petunjuk tertulis yang dituangkan dalam bentuk lembar kegiatan peserta didik (LKPD). LKPD dalam pembelajaran secara umum berfungsi sebagai bahan ajar yang bisa meminimalkan peran pendidik namun lebih mengaktifkan peserta didik, sebagai bahan ajar yang mempermudah peserta didik untuk memahami materi yang diberikan, sebagai bahan ajar yang ringkas dan kaya tugas untuk berlatih, serta memudahkan pelaksanaan pengajaran kepada peserta didik, (Prastowo, 2012). Berdasarkan pendapat tersebut maka guru menggunakan LKPD dalam menyatakan persoalan kepada peserta didik. Penggunaan LKPD ini dapat membuat peserta didik terlibat aktif dengan materi yang dipelajari dan memberikan pengalaman belajar kepada peserta didik dalam mengerjakan soal.

Sebagai seorang pendidik, sudah seharusnya seorang guru mampu memotivasi peserta didik, mengaktifkan proses pembelajaran, membimbing peserta didik, menciptakan suasana belajar yang menyenangkan dan mampu mengajak peserta didik ikut berpartisipasi dalam proses pembelajaran. Seorang guru juga dituntut kreatif dan inovatif dalam menyusun bahan ajar yang dapat mengarahkan peserta didik dalam proses pembelajaran agar tercapainya tujuan pembelajaran. Namun dilapangan sering ditemui bahan ajar yang digunakan guru dalam proses pembelajaran matematika belum memadai. Guru hanya memanfaatkan buku paket matematika dari sekolah sebagai sumber belajar dan tidak ada Lembar Kegiatan Peserta Didik (LKPD) untuk melatih peserta didik mengerjakan soal 
Lembar Kerja Peserta Didik Matematika Berbasis Penemuan Terbimbing Terintegrasi Nilai Keislaman, Arnida Sari, Rena Revita

latihan dalam proses memahami materi pelajaran yang seharusnya dirancang sendiri oleh guru. Dapat disimpulkan bahwa bahan ajar yang ada belum mendukung aktivitas belajar peserta didik.

Berdasarkan uraian tersebut, perlu diadakan suatu perbaikan dalam proses pembelajaran matematika di dalam kelas. Peneliti ingin memberikan suatu masukan yang bermanfaat bagi guru dan peserta didik yaitu LKPD berbasis penemuan terbimbing yang dapat digunakan peserta didik untuk memahami materi pelajaran. LKPD yang akan dikembangkan diharapkan dapat memfasilitasi peserta didik untuk meningkatkan kemampuan komunikasi matematika peserta didik. untuk itu, peneliti akan melakukan penelitian pengembangan dengan judul "Pengembangan LKPD Matematika Berbasis Penemuan Terbimbing Terintegrasi Nilai Keislaman Untuk Memfasilitasi Kemampuan Komunikasi Matematis".

\section{METODE}

Penelitian ini dilaksanakan pada semester ganjil tahun ajaran 2020/2021 pada 5 sekolah di Pekanbaru yaitu SMP IT Al Maarif, MTs Al-Muttaqin Pekanbaru, SMP IT Abdurrab Pekanbaru, SMP IT Al-Izhar Pekanbaru dan MTs Darul Hikmah Pekanbaru. Jenis penelitian yang digunakan dalam penelitian ini adalah penelitian pengembangan (Research and Development/R\&D). Research and Development adalah metode penelitian yang digunakan untuk menghasilkan produk tertentu, dan menguji keefektifan produk tersebut (Sugiyono, 2016). Sedangkan menurut Nana Syaodih dalam Zakariah (Zakariah, Afriani, \& Zakariah, 2020) penelitian dan pengembangan adalah suatu proses atau langkah-langkah untuk mengembangkan suatu produk baru atau menyempurnakan produk yang telah ada, yang dapat dipertanggungjawabkan. Penelitian pengembangan di bidang pendidikan merupakan suatu jenis penelitian yang bertujuan untuk menghasilkan produk-produk untuk kepentingan pendidikan atau pembelajaran berupa LKPD berbasis penemuan terbimbing yang diintegrasikan nilai keislaman.

Model penelitian yang digunakan adalah model ADDIE. Salah satu model desain pembelajaran yang sifatnya lebih generik, ADDIE muncul pada tahun 1990-an yang dikembangkan oleh Reiser dan Mollenda. Model ini, sesuai dengan namanya, terdiri dari lima fase atau tahap utama, yaitu (A)nalysis, (D)esign, (D)evelopment, (I)mplementation, dan (E)valuation (Benny A Pribadi, 2010). Kelima fase atau tahap dalam model ADDIE, perlu dilakukan secara sistemik dan sistematik. Salah satu fungsinya ADDIE yaitu menjadi pedoman dalam membangun perangkat dan infrastruktur program pelatihan yang efektif, dinamis dan mendukung. Model desain sistem pembelajaran yang memperlihatkan tahapan-tahapan dasar desain sistem pembelajaran yang sederhana dan mudah dipelajari adalah model ADDIE. Salah satu desain pembelajaran yang lebih generik, ADDIE muncul pada tahun 1990-an.

Teknik pengumpulan data yang dilakukan untuk uji validitas dan uji praktikalitas adalah angket. Sedangkan untuk uji efektifitas digunakan teknik tes kemampuan matematis. Intrumen yang digunakan untuk uji validitas adalah angket yang diisi oleh para pakar. Sedangkan instrumen untuk uji 
praktikalitas adalah berupa angket respon yang akan diisi oleh peserta didik setelah menggunakan LKPD yang dikembangkan. Kemudian intrumen yang digunakan untuk uji efektifitas adalah soal tes kemampuan matematis yang diberikan kepada peserta didik setelah proses pembelajaran dengan menggunakan LKPD selesai. Teknik analisis data yang digunakan untuk mengolah data hasil pengembangan adalah teknik analisis deskriptif kualitatif untuk menganalisis data yang diperolah berupa komentar maupun saran dari para pakar dan teknik analisis kuantitatif adalah teknik analisis data yang digunakan untuk menganalisis data yang diperoleh dari angket.

Analisis hasil uji validitas LKPD yang dikembangkan dapat dilakukan dengan beberapa langkah, yaitu memberikan skor jawaban dengan kriteria Sangat Baik (skor 5), Baik (skor 4), Cukup Baik (skor 3), Kurang Baik (skor 2), Tidak Baik (skor 1); memberikan nilai persentase dengan rumus:

$$
\text { Tingkat validitas }=\frac{\text { skor diperoleh }}{\text { skor tertinggi }} \times 100 \%
$$

Kemudian menginterpretasikan data berdasarkan tabel berikut:

Tabel 1. Interpretasi Data Validitas LKPD

\begin{tabular}{|c|c|c|}
\hline No & Interval & Kriteria Validitas \\
\hline 1 & $90 \%-100 \%$ & Sangat Valid \\
\hline 2 & $70 \%-89 \%$ & Valid \\
\hline 3 & $50 \%-69 \%$ & Cukup Valid \\
\hline 4 & $30 \%-49 \%$ & Kurang Valid \\
\hline 5 & $20 \%-29 \%$ & Tidak Valid \\
\hline
\end{tabular}

Sumber: diadaptasi dari (Sugiyono, 2016)

Analisis hasil uji praktikalitas LKPD yang dikembangkan dapat dilakukan dengan beberapa langkah, yaitu memberikan skor jawaban dengan kriteria Sangat Baik (skor 5), Baik (skor 4), Cukup Baik (skor 3), Kurang Baik (skor 2), Tidak Baik (skor 1); memberikan nilai persentase dengan rumus:

$$
\text { Tingkat Praktikalitas }=\frac{\text { skor yang diperoleh }}{\text { skor tertinggi }} \times 100 \%
$$

Kemudian menginterpretasian data berdasarkan tabel berikut:

Tabel 2. Interpretasi data kepraktisan LKPD

\begin{tabular}{|c|c|c|}
\hline No & Interval & Kriteria Praktikalitas \\
\hline 1 & $90 \%-100 \%$ & Sangat Praktis \\
\hline 2 & $70 \%-89 \%$ & Praktis \\
\hline 3 & $50 \%-69 \%$ & Cukup Praktis \\
\hline 4 & $30 \%-49 \%$ & Kurang Praktis \\
\hline 5 & $20 \%-29 \%$ & Tidak Praktis \\
\hline
\end{tabular}

Sumber: diadaptasi dari sugiyono 2016

Setelah siswa diberikan pembelajaran dengan menggunakan LKPD matematika berbasis penemuan terbimbing terintegrasi nilai keislaman, di akhir pembelajaran siswa diberikan soal tes guna 
Lembar Kerja Peserta Didik Matematika Berbasis Penemuan Terbimbing Terintegrasi Nilai Keislaman, Arnida Sari, Rena Revita

mengetahui keefektifan LKPD yang dikembangkan terhadap kemampuan matematika siswa. Tingkat efektifitas dapat diketahui dengan membandingkan hasil yang diperoleh siswa dengan nilai KKM. Nilai KKM untuk matematika kelas VII adalah 75 . Nilai $\geq 75$ termasuk kategori tuntas dan nilai $<75$ termasuk kategori tidak tuntas.

\section{HASIL DAN DISKUSI}

\section{Analysis (Analisis)}

Analisis yang dilakukan adalah anlisis kinerja yaitu dengan merinci isi materi ajar dalam bentuk garis besar. Berdasarkan kurikulum 2013 mata pelajaran matematika tingkat SMP/MTs kelas VII. LKPD ini berisi beberapa materi yang berkaitan dengan segi empat yakni Pengertian segi empat, Jenis-jenis segi empat, keliling segi empat, dan luas segi empat. LKPD akan digunakan oleh Siswa kelas VII SMP/MTs yang berusia kurang lebih 11-13 tahun. Pada usia 11 atau 12 tahun ke atas seorang remaja sudah memiliki cara berpikir yang berbeda dari sebelumnya. Piaget mendapatkan tiga pemikiran penting yang mempengaruhi berpikir dikemudian hari. Pertama, Piaget melihat bahwa anak yang berbeda umur menggunakan cara berpikir yang bebeda. Inilah yang menurut Piaget tahap-tahap perkembangan kognitif anak. Kedua, metode klinik digunakannya untuk mengorek pemikiran anak secara lebih mendalam. Metode inilah yang dikembangkan Piaget dalam studinya tentang perkembangan kognitif anak. Ketiga, Piaget berpikir bahwa pemikiran logika abstrak mungkin relevan untuk mememahami pemikiran anak (Ufie, 2017). Namun tidak semua siswa yang berada di tahap awal remaja ini mampu berpikir abstrak. Model penemuan terbimbing merupakan suatu prosedur mengajar yang menitikberatkan studi individual, manipulasi objek-objek, dan eksperimentasi oleh peserta didik sebelum membuat generalisasi sampai peserta didik menyadari suatu konsep.

\section{Design (Desain)}

Tahap design merupakan tahapan untuk merancang LKPD matematika melalui model penemuan terbimbing terintegrasi nilai keislaman serta komponen-komponen yang berkaitan dengan LKPD tersebut. Berikut ini ditampilkan beberapa komponennya setelah dilakukan revisi beserta penjelasannya.

\section{Sampul dan Gambar Awal pada Bab}

Cover atau sampul merupakan salah satu unsur penting terhadap daya tarik siswa untuk membaca. Cover LKPD matematika berbasis penemuan terbimbing terintegrasi nilai keislaman pada awalnya hanya menggunakan lambang bilangan saja, ketika di nilai oleh validator ahli teknologi, validator menyarankan untuk menggunakan gambar yang sesuai dengan materi yang akan dijelaskan mereka temui dalam kehidupan sehingga siswa lebih tertarik. Terlihat seperti Gambar 1. Selanjutnya terdapat gambar di awal bab bertujuan untuk menstimulus siswa sehingga lebih tertarik untuk belajar. Terlihat pada Gambar 2 berikut. 


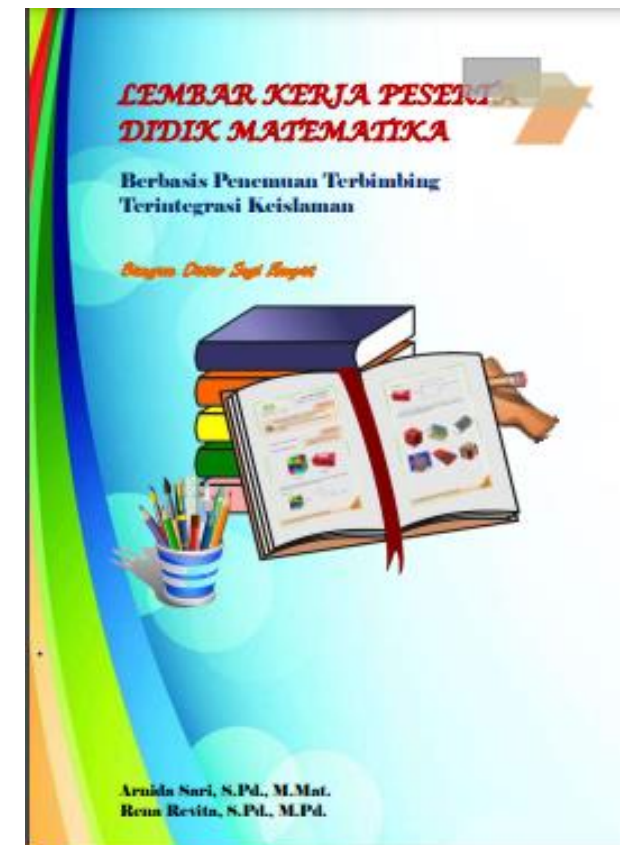

Gambar. 1. Desain Cover Sesudah Revisi

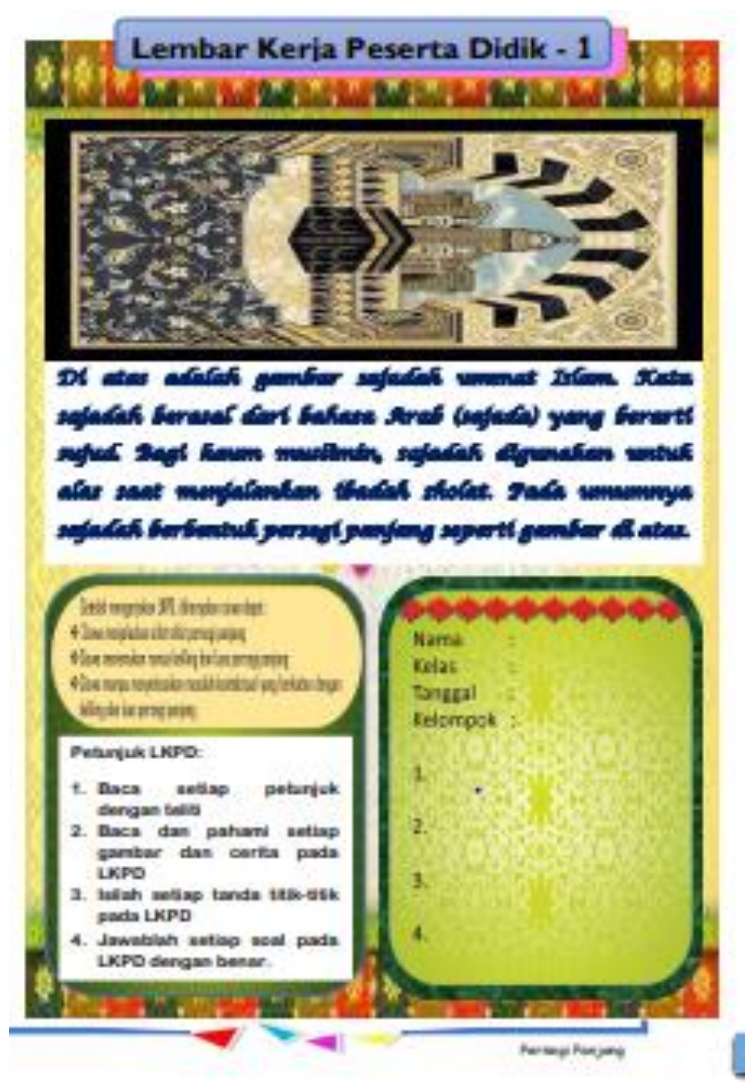

Gambar 2. Desain Gambar Pada Awal Bab

\section{Kegiatan Belajar dan Karikatur}

Tampilan materi disajikan dengan berbagai macam benda-benda nyata yang ada dalam kehidupan sehari-hari. Dapat dilihat pada Gambar 3. Pada LKPD juga terdapat karikatur yang lucu bernuansa islami dan berwarna agar membuat siswa lebih tertarik seperti yang terlihat pada Gambar 4 . 

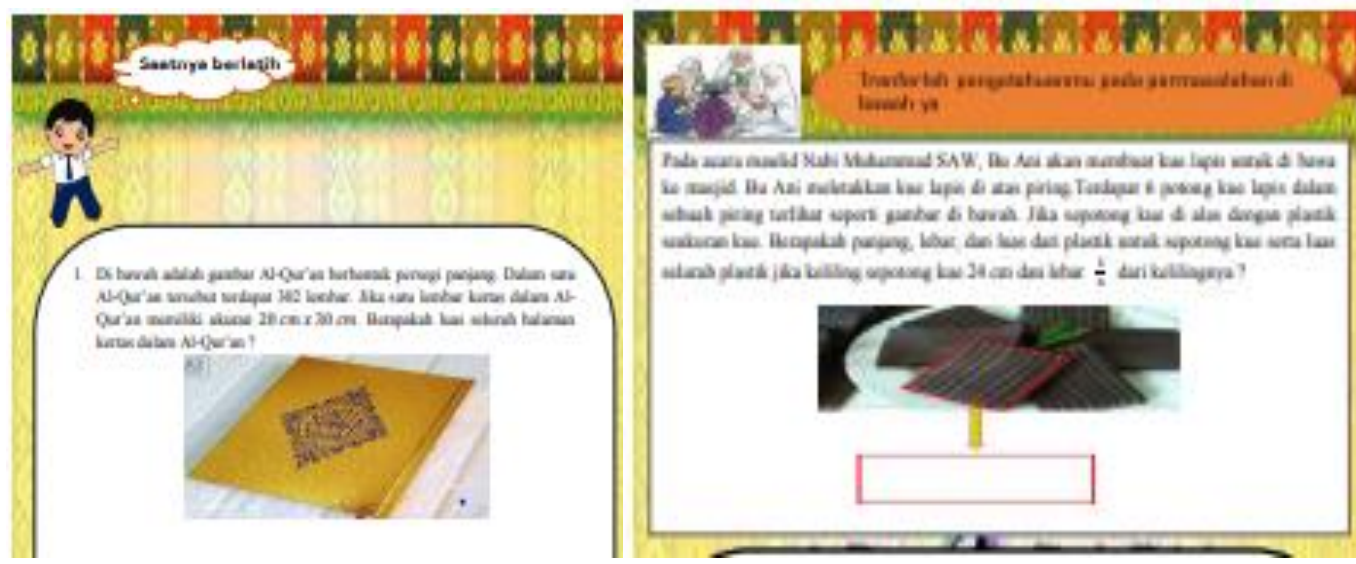

Gambar 3. Desain Kegiatan Belajar
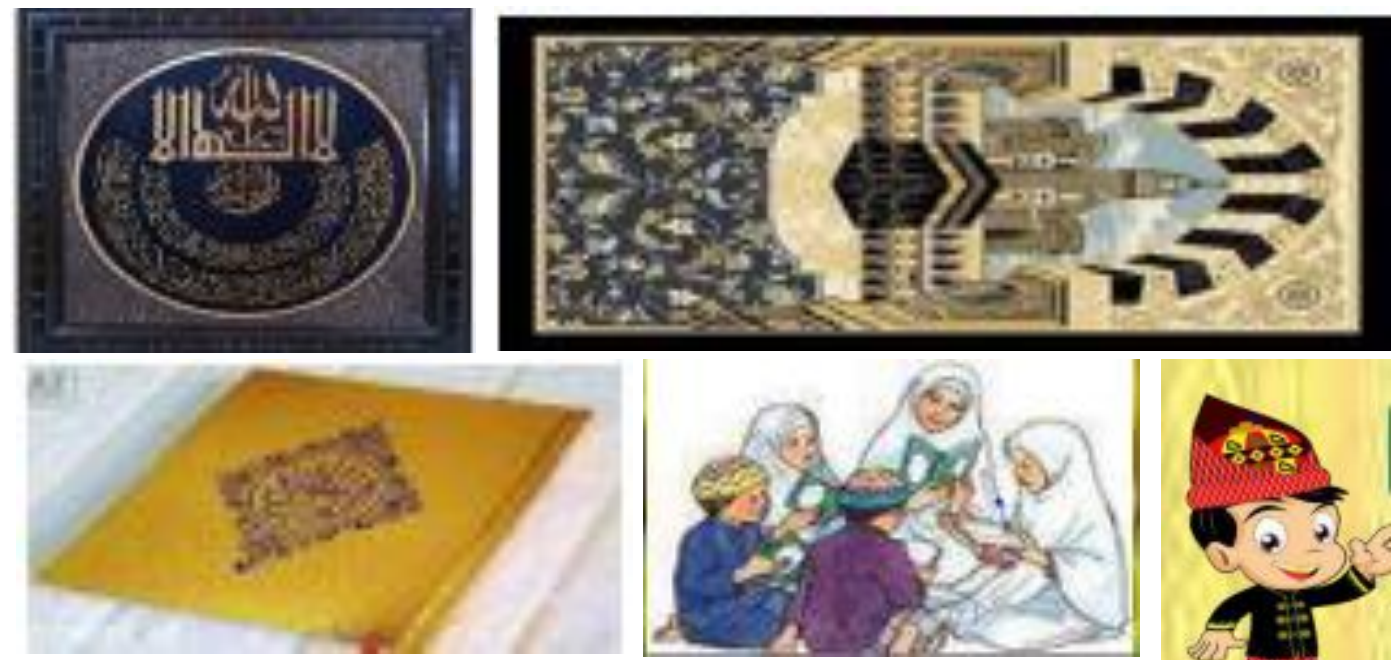

Sumber: Google

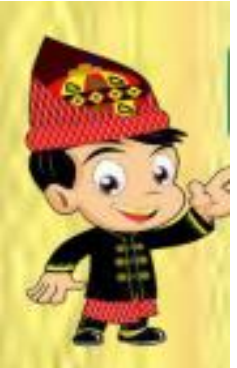

Gambar 4. Desain Karikatur Bernuansa Islami

\section{Development (Pengembangan)}

Setelah selesai proses desain LKPD, kemudian LKPD yang dikembangkan di validasi oleh Validator ahli teknologi pendidikan dan ahli materi pembelajaran matematika dengan menggunakan angket. Angket yang digunakan telah divalidasi oleh Validator ahli instrument. Berdasarkan proses validasi instrumen, validator memberi nilai B yang berarti "dapat digunakan sedikit revisi”. Dengan demikian maka instrumen angket tersebut sudah dapat digunakan untuk menilai LKPD. Setelah angket penilaian sudah valid, kemudian angket tersebut digunakan untuk memvalidasi LKPD yang dikembangkan. Validasi ini bertujuan untuk melihat apakah LKPD yang dibuat sudah layak atau tidak untuk di uji cobakan.

Berdasarkan data hasil penelitian, validator memberi nilai B yang berarti "dapat digunakan sedikit revisi". Dengan demikian maka instrument angket tersebut sudah dapat digunakan untuk menilai LKPD. Setelah selesai, LKPD tersebut dinilai oleh ahli teknologi pendidikan dan ahli materi pembelajaran dengan menggunakan angket penilaian LKPD. Berikut hasil validitas oleh ahli teknologi pendidikan. 
Tabel 3. Hasil Validitas oleh Ahli Teknologi Pendidikan

\begin{tabular}{|c|l|c|c|}
\hline No. & \multicolumn{1}{|c|}{ Kriteria Tampilan LKPD } & Nilai Validasi & Kriteria \\
\hline 1 & Penggunaan huruf dan tulisan & $97,14 \%$ & Sangat Valid \\
\hline 2 & Desain LKPD & $94,67 \%$ & Sangat Valid \\
\hline 3 & Penggunaan gambar & $93,33 \%$ & Sangat Valid \\
\hline 4 & LKPD berpenampilan menarik & $100 \%$ & Sangat Valid \\
\hline \multicolumn{2}{r}{ Rata-rata } & $96,3 \%$ & Sangat Valid \\
\hline
\end{tabular}

Berdasarkan Tabel 3, jelas terlihat bahwa persentase keseluruhan dari penilaian oleh kedua ahli teknologi pendidikan adalah Sangat Valid, karena berada pada rentang 90\% sampai 100\%, sehingga LKPD pembelajaran sedikit memerlukan revisi. Namun komentar dan saran dari ahli teknologi pendidikan dijadikan bahan perbaikan untuk menyempurnakan LKPD pembelajaran. Berikut hasil validitas oleh ahli materi pembelajaran.

Tabel 4. Hasil Validitas oleh Ahli materi Pembelajaran

\begin{tabular}{|c|c|c|c|c|c|}
\hline No & Variabel Validitas & Indikator & $\begin{array}{c}\text { Nomor } \\
\text { Pernyataan }\end{array}$ & $\begin{array}{c}\text { Nilai } \\
\text { Validitas }\end{array}$ & Kriteria \\
\hline \multirow{3}{*}{1} & \multirow{3}{*}{ Syarat Didaktif } & $\mathrm{A}$ & $1,2,3$ & $97,78 \%$ & Sangat Valid \\
\hline & & B & 4,15 & $93,33 \%$ & Sangat Valid \\
\hline & & $\mathrm{C}$ & $6,7,27$ & $100 \%$ & Sangat Valid \\
\hline \multirow{5}{*}{2} & \multirow{5}{*}{ Syarat Konstruktif } & A & $21,22,23$ & $100 \%$ & Sangat Valid \\
\hline & & B & $8,9,10,11$ & $98,33 \%$ & Sangat Valid \\
\hline & & $\mathrm{C}$ & 12 & $93,33 \%$ & Sangat Valid \\
\hline & & $\mathrm{D}$ & 26 & $93,33 \%$ & Sangat Valid \\
\hline & & $E$ & 20 & $100 \%$ & Sangat Valid \\
\hline \multirow{5}{*}{3} & \multirow{5}{*}{$\begin{array}{l}\text { Syarat Penemuan } \\
\text { terbimbing }\end{array}$} & $\mathrm{A}$ & 17 & $100 \%$ & Sangat Valid \\
\hline & & $\mathrm{B}$ & 5 & $100 \%$ & Sangat Valid \\
\hline & & $\mathrm{C}$ & 19 & $86,67 \%$ & Sangat Valid \\
\hline & & $\mathrm{D}$ & 24 & $100 \%$ & Sangat Valid \\
\hline & & $\mathrm{E}$ & 25 & $100 \%$ & Sangat Valid \\
\hline \multirow{2}{*}{4} & \multirow{2}{*}{$\begin{array}{c}\text { Syarat Terintegrasi } \\
\text { nilai-nilai Keislaman }\end{array}$} & A & 13,14 & $96,67 \%$ & Sangat Valid \\
\hline & & $\mathrm{B}$ & 16,18 & $90 \%$ & Sangat Valid \\
\hline \multicolumn{4}{|c|}{ Rata-rata } & $97,03 \%$ & Sangat Valid \\
\hline
\end{tabular}

Berdasarkan Tabel 4, jelas terlihat bahwa persentase keseluruhan dari penilaian kedua ahli materi pembelajaran adalah Sangat Valid karena berada pada rentang 90\% - 100\%. Berikut hasil penilaian secara keseluruhan:

Tabel 5. Hasil Validitas Secara Keseluruhan

\begin{tabular}{|c|c|c|}
\hline No & Variabel Validitas LKPD & Persentasi keidealan \\
\hline 1 & Ahli Teknologi Pendidikan & $96,30 \%$ \\
\hline 2 & Ahli Materi Pembelajaran & $97,03 \%$ \\
\hline \multicolumn{2}{|c|}{ Rata-rata } & $96,74 \%$ (Sangat Valid) \\
\hline
\end{tabular}

Berdasarkan Tabel 5, jelas terlihat bahwa persentase keseluruhan dari penilaian para ahli adalah Sangat Valid, karena berada pada rentang 90\% - 100\%, sehingga LKPD pembelajaran sudah 
Lembar Kerja Peserta Didik Matematika Berbasis Penemuan Terbimbing Terintegrasi Nilai Keislaman, Arnida Sari, Rena Revita

sangat layak untuk digunakan. Namun saran dan komentar dari ahli dijadikan bahan perbaikan dalam penyempurnaan LKPD ini.

\section{Implementation (Implementasi)}

Setelah direvisi berdasarkan saran dari para ahli baik teknologi pendidikan maupun materi pembelajaran. Selanjutnya LKPD tersebut di uji cobakan pada kelompok terbatas melalui angket kelayakan LKPD tersebut. LKPD diberikan sebelum siswa memasuki materi yang akan dipelajari. Dengan demikian siswa bisa belajar di rumah sebelum melakukan proses pembelajaran di dalam kelas. LKPD yang diberikan kepada siswa dilengkapi dengan konten, warna dan gambar yang menarik.

Uji coba dilakukan di kelas VII SMP IT Al Ma'arif Pekanbaru yang berjumlah 20 siswa dan kelas VII SMP IT Abdurrab berjumlah 15 siswa. Hasil penilaian oleh siswa terhadap LKPD yang dikembangkan dapat dilihat pada lampiran. Distribusi skor angket uji praktikalitas dapat dilihat pada lampiran. Hasil penilaian uji praktikalitas pada saat uji coba dipaparkan dalam Hasil penilaian uji praktikalitas pada saat uji coba dipaparkan dalam Tabel 6 sebagai berikut.

Tabel 6. Persentase Praktikalitas Pada Saat Uji Coba

\begin{tabular}{|c|l|c|c|}
\hline No & \multicolumn{1}{|c|}{ Variabel Praktikalitas } & $\begin{array}{c}\text { Nilai } \\
\text { Praktikalitas }\end{array}$ & Kriteria \\
\hline 1. & Minat siswa dan tampilan LKPD & $84 \%$ & Praktis \\
\hline 2. & Penggunaan LKPD & $83,4 \%$ & Praktis \\
\hline 3. & Hasil Belajar dan Materi & $83,4 \%$ & Praktis \\
\hline 4. & Terintegrasi Nilai-Nilai Keislaman & $86 \%$ & Praktis \\
\hline 5. & Waktu & $84 \%$ & Praktis \\
\hline 6. & Evaluasi & $84,6 \%$ & Praktis \\
\hline \multicolumn{2}{|c|}{ Rata-rata } & $84 \%$ & $84 \%$ \\
\hline
\end{tabular}

Berdasarkan Tabel 6, jelas terlihat bahwa persentase keseluruhan dari penilaian siswa pada uji coba kelompok terbatas adalah Praktis, karena berada pada rentang 70\% - 89\%, sehingga LKPD pembelajaran sedikit memerlukan revisi. Namun saran dan komentar dari siswa dijadikan bahan pertimbangan dalam penyempurnaan LKPD ini. Selanjutnya tahap pengembangan LKPD dilanjutkan ke tahap uji efektifitas, dengan memberikan siswa soal tes matematika. Berikut data hasil efektifitas LKPD terhadap kemampuan matematika siswa.

Tabel. 7 Hasil Efektifitas LKPD Matematika

\begin{tabular}{|c|c|c|c|}
\hline No & Jumlah Siswa & Interval & Kriteria \\
\hline \multicolumn{4}{|c|}{ SMP IT Al Ma'arif Pekanbaru } \\
\hline 1 & 17 Orang & $\geq 75$ & Tuntas \\
\hline 2 & 3 orang & $<75$ & Tidak Tuntas \\
\hline \multicolumn{4}{|c|}{ SMP IT Abdurrab Pekanbaru } \\
\hline 1 & 12 Orang & $\geq 75$ & Tuntas \\
\hline 2 & 3 orang & $<75$ & Tidak Tuntas \\
\hline \multicolumn{2}{|c|}{ Rata-rata } & $81,81 \%$ & Tuntas \\
\hline
\end{tabular}


Berdasarkan Tabel 7, sebanyak 85\% siswa kelas VII yaitu 17 siswa dari 20 siswa SMP IT Al Ma'arif Pekanbaru dan 12 dari 15 siswa SMP IT Abdurrab Pekanbaru telah tuntas dalam pembelajaran dengan nilai di atas KKM (75). Presentase rata-rata juga menunjukkan jauh di atas KKM yaitu mencapai angka 81,81\%, maka LKPD ini memiliki efektifitas yang tinggi

\section{Evaluation (Evaluasi)}

Tahap terakhir adalah evaluation (evaluasi). Pada tahap ini dilakukan revisi terhadap LKPD yang telah dikembangkan. Perbaikan dilakukan berdasarkan hasil penilaian dari validator maupun siswa. semua saran perbaikan yang diberikan terhadap LKPD yang dikembangkan direvisi dengan baik.

\section{KESIMPULAN}

Berdasarkan hasil penelitian yang telah diuraikan sebelumnya maka dapat diambil kesimpulan bahwa telah dihasilkan LKPD matematika berbasis penemuan terbimbing terintegrasi nilai keislaman pada materi segi empat yang sangat valid, praktis dan efektif. Ini dapat dilihat dari keefektifan yang diolah dari data hasil ujian siswa dan menunjukkan bahwa LKPD membantu siswa dalam proses pembelajaran.

\section{REFERENSI}

Ariesta, P. N., \& Awalludin, S. A. (2021). Pengaruh Model Pembelajaran Penemuan Terbimbing Berbantuan LKPD Terhadap Kemampuan Komunikasi Matematis Siswa. Journal of Authentic Research on Mathematics Education (JARME), 3(1), 54-67. https://doi.org/10.37058/jarme.v3i1.2427

Benny A Pribadi. (2010). Model Desain Sistem Pembelajaran. Jakarta: Dian Rakyat.

Dede. (2016). Penerapan Metode Penemuan Terbimbing Untuk Meningkatkan Kemampuan Pemecahan Masalah Matematis, Kemampuan Komunikasi Matematis, dan Analisis Kemandirian Belajar peserta didik SMA".

Destrini, H., Nirwana, N., \& Sakti, I. (2018). Penerapan Model Pembelajaran Penemuan Terbimbing (Guided Discovery Learning) untuk Meningkatkan Hasil Belajar dan Keterampilan Proses Sains Siswa. Jurnal Kumparan Fisika, 1(1 April), 13-21. https://doi.org/10.33369/jkf.1.1.13-21

Fitriani, V., \& Afri, L. E. (2020). Pengembangan Lembar Kerja Siswa Matematika Berbasis Penemuan Terbimbing Untuk Siswa Kelas VII Sekolah Menengah Pertama Pada Materi Segiempat. Jurnal Absis: Jurnal Pendidikan Matematika Dan Matematika, 3(1). Diambil dari https://journal.upp.ac.id/index.php/absis/article/view/494

Kosasih. (2014). Strategi Belajar dan Pembelajaran Implementasi Kurikulum 2013. Bandung: Yrama Widya.

Permendikbud. (2016). Permendikbud No 21 Tahun 2016. Diambil dari https://bsnp-indonesia.org/ wp-content/uploads/2009/06/Permendikbud_Tahun2016_Nomor021_Lampiran.pdf 
Lembar Kerja Peserta Didik Matematika Berbasis Penemuan Terbimbing Terintegrasi Nilai Keislaman, Arnida Sari, Rena Revita

Prastowo, A. (2012). Panduan Kreatif Membuat Bahan Ajar Inovatif. Yogyakarta: Diva Press.

Risnawati. (2008). Strategi Pembelajaran Matematika. Pekanbaru: Suska Press.

Sani, Hartoyo, A., \& Yani, A. (2017). Pengembangan Lembar Kerja Siswa Berstruktur Metode Penemuan Terbimbing Untuk Meningkatkan Kemampuan Komunikasi Matematis Siswa. Jurnal Pendidikan dan Pembelajaran Khatulistiwa, 6(1). Diambil dari https://jurnal.untan.ac.id/index.php/jpdpb/article/view/18173

Sugiyono. (2016). Metode Penelitian Pendidikan (Pendekatan Kuantitatif, Kualitatif, dan R\&D). Bandung: Alfabeta.

Suparsih, S. (2018). Kemampuan Komunikasi Matematis Dengan Pembelajaran Penemuan Terbimbing. Tajdidukasi: Jurnal Penelitian Dan Kajian Pendidikan Islam, 7(1), 91-100. https://doi.org/10.47736/tajdidukasi.v7i1.84

Ufie, A. (2017). Implementasi Teori Genetik Epistemology Dalam Pembelajaran Guna Memantapkan Perkembangan Kognitif Anak Usia Sekolah. Jurnal Pedagogika dan Dinamika Pendidikan, 6(1), $25-43$.

Yuniarti, Y. (2014). Pengembangan Kemampuan Komunikasi Matematis dalam Pembelajaran Matematika di Sekolah Dasar. EduHumaniora|Jurnal Pendidikan Dasar Kampus Cibiru, 6(2). https://doi.org/10.17509/eh.v6i2.4575

Zakariah, M. A., Afriani, V., \& Zakariah, K. M. (2020). Metodologi penelitian kualitatif, kuantitatif, action research, research and development $(R n D)$. Yayasan Pondok Pesantren Al Mawaddah Warrahmah Kolaka. 